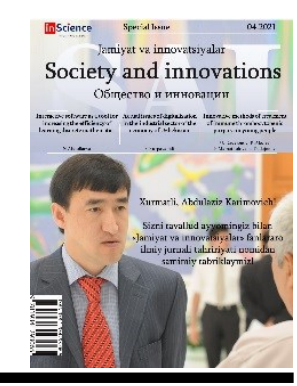

\title{
Innovative methods of treatment of immune thrombocytopenic purpura in young people
}

\section{Utkur DADAJONOV ${ }^{1}$ Kattabek ABDIEV ${ }^{2}$ Feruza MAMATKULOVA ${ }^{3}$ Uktam DADAJONOV 4}

Samarkand State Medical Institute

\begin{tabular}{l} 
ARTICLE INFO \\
\hline Article history: \\
Received March 2021 \\
Received in revised form \\
20 March 2021 \\
Accepted 15 April 2021 \\
Available online \\
20 May 2021
\end{tabular}

Keywords:

immune system,

meditation,

youth,

blood,

treatment,

exercise.

\begin{abstract}
This article is about describing innovative methods of treatment of immune thrombocytopenic purpura in young people. Moreover, a great many useful instructions are given in order to enhance immune system.

2181-1415/C 2021 in Science LLC.

This is an open access article under the Attribution 4.0 International (CC BY 4.0) license (https://creativecommons.org/licenses/by/4.0/deed.ru)
\end{abstract}

\section{Yoshlarda immun trombotsitopenik purpurani davolashning innovatsion usullari}

\author{
Kalit so'zlar: \\ immunitet tizimi, \\ meditatsiya, \\ yoshlik, \\ qon, \\ davolash, \\ mashqlar.
}

\author{
ANNOTATSIYA \\ Ushbu maqola yoshlarda immun trombotsitopenik pururani \\ davolashning innovatsion usullarini tavsiflash haqida. Bundan \\ tashqari, immunitetni yaxshilash uchun juda ko'p foydali \\ ko'rsatmalar berilgan.
}

\footnotetext{
${ }^{1}$ Assistant professor, Department of Hematology, Samarkand State Medical Institute, Samarkand, Uzbekistan

${ }^{2}$ Assistant professor, Department of Hematology, Samarkand State Medical Institute, Samarkand, Uzbekistan

${ }^{3}$ Lecturer, Department of Hematology, Samarkand State Medical Institute, Samarkand, Uzbekistan

${ }^{4}$ Lecturer, Department of Hematology, Samarkand State Medical Institute, Samarkand, Uzbekistan
} 


\section{Инновационные методы лечения иммунной тромбоцитопенической пурпуры у лиц молодого возраста}

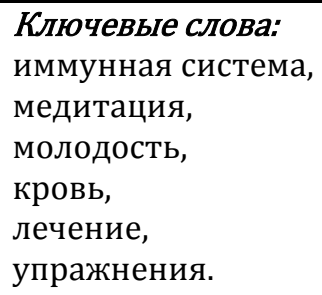

\section{АННОТАЦИЯ}

Статья посвящена описанию инновационных методов лечения иммунного тромбоцитопенического гнойного поражения у молодых людей. Кроме того, было дано много полезных рекомендаций по повышению иммунитета.

To begin with, people have immune thrombocytopenic purpura (ITP), it means that their blood is not pumping as much as it should, which puts you at risk for excessive bleeding. The only way to treat ITP is with traditional medications prescribed by your hematologist. The goal of treatment is to increase the number of platelets and reduce the risk of sudden bleeding from the inside and outside. However, your medication may not address all of the effects of ITP, including any changes in your mood and energy levels. Additional treatment may help here. The National Center for Complementary and Integrative Health (NCCIH) defines an additional approach to health care as a non-traditional practice used in conjunction with traditional medicine. The use of complementary and basic methods is also the foundation of health. Additional approaches are not intended to replace ITP medications, but they can be used together for health. Do you know how complementary therapy can work with your ITP treatment plan? These nine methods will help you get started.

\section{Meditation}

Breathing exercises - especially meditation - are at the heart of complementary medicine. It helps to relax your mind and body, improve your mood and refresh you.

You don't have to be a Zen master to benefit from meditation. If you are new to breathing exercises, start with a minute or two. Pay close attention to your breathing as you take deep breaths and exhale. You may even want to focus your eyes on a happy image like a mountain or a beach.

Make sure you meditate regularly twice a day to get really positive results. It only takes 10-15 minutes to complete the trick. Be patient with yourself, because the quiet side goes into practice.

\section{Energy balancing work}

People with ITP are advised to spend time on energy therapy, such as qi gong or reiki. Qi gong is similar to tai chi, which combines breathing techniques controlled by slow physical movements. Such energy balancing activities improve your energy levels by improving blood circulation in the body. Reiki, on the other hand, depends on touch. A qualified therapist uses his hands to restore energy through massage and other manipulations.

\section{Regular exercise}

Exercise is a great way to lose or manage weight. It can also help improve your cardiovascular health, strengthen your muscles, and reduce any depression and / or anxiety.

If you have an ITP, it is understandable that you have a strong concern about the risk of injury while working. While self-exercise does not cause any bleeding, there can be injuries that can occur as a result of exercise. Still, the harm of regular exercise is huge. 
Focus on low-impact jobs. For example, you can try walking or swimming. Choose an activity you like and follow it. Gradually increase the intensity so that you get stronger over time.

The Centers for Disease Control and Prevention (CDC) recommends an average intensity of at least 150 minutes of exercise each week to achieve significant results.

\section{Nutrition guidelines}

While there is no specific diet to treat ITP, consuming certain foods (and avoiding others) can help you feel better and improve your long-term health. . Your doctor will recommend a whole diet that focuses on plenty of vegetables, grains, and lean protein. Good nutrition will help you get your daily workouts and workouts done with less exercise [2. P. 45].

It can also help you keep a nutrition journal so you can keep track of how you are eating depending on any changing or worsening symptoms. Then you may know that you should refrain from eating.

\section{Necessary sleep}

It is common to experience daytime fatigue when living with an ITP. It is associated with blood loss. Of course, not getting enough sleep at night can lead to fatigue during the day.

The Platelet Disease Support Association (PDSA) recommends at least seven hours of sleep each day. They also point out that Ayurvedic media recommends going to bed before $10 \mathrm{am}$. To wake up before 6 in the morning and get good results, follow a normal sleep routine and avoid daytime sleepiness.

\section{Mental and physical exercise}

Exercise, which involves both your mind and body, is one of the most popular complementary therapies, reports NCCIH. You have probably heard of two mental body exercises - yoga and tai chi. As a bonus, these exercises have less impact and help you build flexibility and muscle mass.

If you want to do mental exercises, first go through professional training to learn the necessary techniques. This will help you avoid injuries. Talk to your teacher in advance about the situation in a way that will help you succeed in class as much as you can. [4. P. 18].

\section{Stress reduction}

Stress is a known inflammatory agent that causes long-term health problems, for example, mental disorders and cardiovascular diseases. Stress status does not directly affect the level of platelets, constant fatigue status can lead to fatigue enhances and can put you at risk of anxiety and depression.

Meditation itself can reduce stress, but it is very important to find other ways to reduce stress in your life. Consider the list of everyday affairs. Is there anything you can leave or hand over to someone else? Do not feel guilty when asking for help. We all need help from time to time, and your health is your priority.

\section{Clean and tidy living areas}

For most people, living in a restless and restless environment increases stress and affects our mood. PDSA recommends feng shui to help you feel more comfortable when you are at home. The ancient Chinese practice was to get rid of noise and things that were no longer needed.

If feng shui isn't your thing, you can start small with something like buying a new plant or mural to revitalize your soul. Or you can try to fix things you already own to lift your spirits.

The thrombocytopoiesis This is the process of platelet formation and excretion. This process occurs in the bone marrow just like erythropoiesis and granulopoiesis. Platelet formation involves two stages: megakaryopoiesis and thrombocytopoiesis. Megakaryopoiesis 
begins before a mature megakaryocyte is formed from the discovery cell of the myeloid progeny.

Thrombocytopoiesis, on the other hand, involves a series of events through which megakaryocytes pass. This cell receives different signals depending on its location.

As long as the cell is inside the osteoblastic stroma, it is inhibited, but when it leaves the extracellular space of the vascular compartment, it is activated by the presence of stimulants.

These substances are background Wilbrand factor, fibrinogen, and vascular endothelial growth factor. Upon activation, the cytoplasmic processes of the megakaryocyte, called the propeletelet, break down to form the propeletelet and platelets.

Due to the process of platelet regulation, homeostasis in terms of platelet turnover can be maintained. Thrombopoietin, interleukin 3 (IL3), IL 6, and IL 11 are available as factors that stimulate thrombocytopoiesis. And inhibitory factors are platelet factor 4 and variable growth factor (TGF) b.

The views expressed require the distinction between the concepts of innovative educational technologies and innovative education as follows:

- Innovative, educational technologies and programs are all educational technologies that create and develop pedagogical innovation is the result.

- Innovative education is an innovative educational technologies and programs in which the teacher is the result of innovative activity, the learner is the creator (generation) of innovative ideas;

- The mono-innovation of production (innovation of specialists) corresponds to the fact that education is not mono-innovation - (pedagogical innovation), its innovation, pedagogical innovation, their consequences, the innovation of the learners. The urgency of the issue here is the development of existing "mono" innovative educational technologies to a "bi-innovative" state [1. P. 12]

These are confirmed by their own practical evidence in the form of experiments and inventions created by a number of foreign students. Here, based on the achievements of modern science, it is proved that the theory of solving inventive problems can be solved through IMEN, that is, through the implementation of strong, talented thinking. A number of developed laboratories (IMEN) in developed countries have developed a new method for IMEN pedagogy called "inventing knowledge". The basis of integration of IMEN was developed in conjunction with all the most widespread innovative pedagogical technologies. An additional effect is the ability to write different pedagogical technologies in the language of practical dialectics. The process of global change, economic and socio-cultural development of our country. Changes in the field require serious attention to the specialists trained in the education system. In the 8090s, the system of training, retraining and advanced training in the field of pedagogical education has become an innovative system as a single and integrated system. We see that he turned his attention to:

- decentralization of education has allowed the independent development of this field in certain regions and the formation of a "portfolio of orders" for certain specialists;

- democratization of higher education institutions provided an opportunity to ensure independence in determining the form, means and conditions of the pedagogical process; provided opportunities for the educator to design his / her pedagogical activity in accordance with the types of secondary schools and to use the subject he / she teaches as a means of student development and to take into account the needs of secondary schools in this regard; 
- considers the need to satisfy the individual interests of the student, designed to develop individual educational programs, including the ability to choose the content and level of pedagogical education; it allows to train professional educators in a short period of time on the basis of different levels of capabilities. Although the above-mentioned processes have been strongly influenced in certain periods, it has acknowledged that there is a certain dialectical interrelationship between innovative processes in relation to traditional training. Without focusing on the unique aspects of each of traditional and innovative education.

Scientists distinguish the concept of periodicity of life in the analysis of the microstructure of the innovation process. This is because the concept is a measurable process in relation to innovation. The scheme of the innovation process is given in the pedagogical literature.

It includes the following stages:

1. The stage of birth of a new idea or the concept of novelty, also called the stage of discovery.

2. Invention, that is, the stage of creating something new.

3. The stage of being able to put the innovation into practice.

4. Dissemination of innovation, the stage of its widespread implementation.

5. The dominant stage of innovation in a particular field. At this stage, the novelty loses its novelty, and an effective alternative emerges.

6 . The phase of narrowing the scope of innovation by replacing it with a new alternative [3. P. 26].

In conclusion the outcomes from the research show that young generation should stick to the rules and instructions which have been presented. These works are implemented by means of innovative ways. Mentioned methods are considered to be most useful, as well as necessary ones.

\section{REFERENCES:}

1. Kamoldinova Diyora, Innovative methods in education development and introduction. Andijon 2013 - P. 55.

2. Mahmudov M. Ta'lim natijasini loyihalash. // "Pedagogik mahurat", 2003-yil, 1-son. - B. 8-10.

3. Ruiz-Gil V. Diagnosis and treatment of immunological thrombocytopenic purpura. Rev Med Hered, 2015; 26 (4): 246-255. Available at: scielo.org.

4. Thrombopoiesis.Wikipedia, the free encyclopedia. 20:02, 5 September 2017 UTC. June 10, 2019, 02:05 Available at: es.wikipedia.org. 